\title{
Effects of a Monensin Controlled-Release Capsule or Premix on Attenuation of Subacute Ruminal Acidosis in Dairy Cows
}

\author{
T. Mutsvangwa, ${ }^{\star}$ J. P. Walton, ${ }^{\star}$ J. C. Plaizier,§ T. F. Duffield, $\dagger$ \\ R. Bagg, $¥$ P. Dick, $¥$ G. Vessie, $¥$ and B. W. McBride* \\ *Department of Animal and Poultry Science, \\ University of Guelph, \\ Guelph, ON, Canada N1G 2W1; \\ $\S$ Department of Animal Science, \\ University of Manitoba, \\ Winnipeg, MB, Canada R3T 2N2; \\ †Department of Population Medicine, \\ University of Guelph; and \\ ‡Elanco Animal Health/Provel Division, Eli Lilly Canada Inc., \\ Research Park Centre, \\ Guelph, ON, Canada N1G 4T2
}

\begin{abstract}
The effects of monensin, administered either as a controlled release capsule (CRC) or a premix, on attenuating grain-induced subacute ruminal acidosis (SARA) and on ruminal fermentation characteristics in Holstein cows receiving a total mixed ration were investigated in two experiments. In both experiments, six multiparous, rumen-fistulated Holstein cows were used in a two-treatment, two-period crossover design with 6wk periods. In Experiment 1, treatments were either a monensin CRC or a placebo CRC. In Experiment 2, treatments were either a monensin premix or a placebo premix. In both experiments, at the beginning of wk 4 SARA was induced in experimental cows for a 10-d period with a grain challenge model, and ruminal $\mathrm{pH}$ was measured continuously using indwelling $\mathrm{pH}$ probes. The administration of monensin either as a $\mathrm{CRC}$ or a premix had no effect on ruminal $\mathrm{pH}$ characteristics. Neither monensin CRC nor premix had an effect on ruminal volatile fatty acid concentrations, but reduced the acetate:propionate ratio. Monensin premixtreated cows were observed to have increased milk yield, largely as a result of a higher dry matter intake in monensin-treated cows compared to control cows. Milk fat content and yield were lower in monensintreated cows compared to placebo-treated cows during SARA. In conclusion, there is no evidence that monensin was efficacious in raising ruminal $\mathrm{pH}$ during SARA under the conditions employed in this study.
\end{abstract}

Received May 16, 2002.

Accepted July 8, 2002.

Corresponding author: B. W. McBride; e-mail: bmcbride@ uoguelph.ca.
(Key words: dairy cow, monensin, ruminal acidosis, milk production)

Abbreviation key: $\mathbf{C R C}=$ controlled-release capsule, SARA = subacute ruminal acidosis.

\section{INTRODUCTION}

In early lactation, high-yielding dairy cows cannot consume enough DM to meet nutrient demands for rapidly increasing milk production (NRC, 1989). To meet these nutrient demands, cows are often changed from a high-fiber diet to an energy-dense diet that is higher in grain and lower in fiber. This rapid change to a diet that is high in readily fermentable carbohydrates can result in a decrease in ruminal $\mathrm{pH}$ due to the accumulation of VFA and lactate, resulting in ruminal acidosis (Owens et al., 1998), which can be acute or subacute. In acute ruminal acidosis, a rapid increase in total acid (i.e., VFA + lactate) supply from the rumen (Owens et al., 1998), leads to a drop in ruminal $\mathrm{pH}$, and a ruminal $\mathrm{pH}$ of 5.2 is generally considered a threshold (Owens et al., 1998). Cows with acute ruminal acidosis will exhibit clinical signs of illness, including blood acidosis, leg stiffness, laminitis, ruminal lesions, and in some cases death (Nocek, 1997). In subacute ruminal acidosis (SARA), cows do not typically exhibit any clinical signs of illness; however, feed intake and milking performance are often depressed. As in acute acidosis, ruminal $\mathrm{pH}$ drops during SARA, and usually lies between 5.2 and 5.6 (Owens et al., 1998).

Monensin, an ionophore, has been reported to have a variety of beneficial effects in ruminants. Monensin exerts its effects primarily by selectively altering the balance of ruminal microbes (Bergen and Bates, 1984). Monensin supplementation in ruminant diets has been reported to increase ruminal production of propionate 
(Bergen and Bates, 1984; Weiss and Amiet, 1990), reduce methanogenesis (Armentano and Young, 1983; Schelling, 1984), increase diet digestibility (Schelling, 1984; Plaizier et al., 2000), reduce ruminal degradation of dietary protein and increase flow of AA to post-ruminal sites (Russell and Strobel, 1989; Yang and Russell, 1993), and increase N retention (Schelling, 1984, Plaizier et al., 2000). In early-lactating dairy cows, monensin reduced blood concentrations of $\beta$-hydroxybutryate (BHB) and increased blood glucose concentrations (Duffield et al., 1998a, Green et al., 1999), and this was associated with a reduced incidence of subclinical ketosis (Duffield et al., 1998b). In several studies with dairy cows, monensin reduced DMI (Ramanzin et al., 1997; Sauer et al., 1998; Van der Werf et al., 1998) and increased milk production (Hayes et al., 1996; Van der Werf et al., 1998; Duffield et al., 1999), suggesting that monensin might increase the efficiency of feed utilization for milk production. Some studies (Sauer et al., 1998; van der Werf et al., 1998) have observed that monensin decreased milk fat content in dairy cows, while others (Duffield et al., 1999; Green et al., 1999) have not. Milk contents of protein and lactose were not affected by monensin (van der Werf et al., 1998; Duffield et al., 1999).

In previous experiments with beef cattle consuming high-grain diets, monensin reduced the characteristic post-prandial decline in ruminal $\mathrm{pH}$ (Nagaraja et al., 1985; Burrin and Britton, 1986). In a study by Cooper and Klopfenstein (1996) in which they monitored ruminal $\mathrm{pH}$ and feed intake continuously in beef steers on high grain finishing diets, monensin was efficacious in elevating average ruminal $\mathrm{pH}$ and decreasing the area of ruminal $\mathrm{pH}$ below 5.6. Few trials have evaluated the effects of monensin on ruminal $\mathrm{pH}$ in dairy cows. Green et al. (1999) reported that monensin increased ruminal $\mathrm{pH}$ in transition dairy cows, but other workers (Haimoud et al., 1995; Ruiz et al., 2001) did not detect an increase in ruminal $\mathrm{pH}$ in monensin-treated dairy cows. A shortcoming with these studies was that ruminal $\mathrm{pH}$ was measured in spot samples obtained via ruminal cannula or by stomach tube at various intervals after feeding, and this is not necessarily representative. Additionally, there was the possibility of salivary contamination with stomach tubing, which might have elevated ruminal fluid $\mathrm{pH}$ in the study by Green et al. (1999). The objectives of this study, therefore, were to determine the efficacy of monensin, administered either as a controlled-release capsule (CRC) or as a premix, on attenuation of experimentally induced SARA, and its effects on ruminal fermentation characteristics in Holstein dairy cows.

\section{MATERIALS AND METHODS}

\section{Experiment 1}

Animals and experimental design. Six multiparous Holstein dairy cows $(630.5 \pm 35.4 \mathrm{~kg}$ BW; $81.2 \pm$ 49.6 DIM) were used in this study. The experiment was run as a two-treatment, two-period crossover design with 6 -wk periods. At the beginning of the experiment, cows were randomly assigned to either a monensin CRC $(n=3)$ or a placebo CRC $(n=3)$. After the first experimental period, treatments were then switched. The experiment was conducted in the Physiology Wing at the Elora Dairy Research Center (University of Guelph, Guelph, ON) from February through May 2001. Animals were cared for and handled in accordance with the Canadian Council on Animal Care regulations, and the University of Guelph Animal Care Committee approved their use for this experiment.

Experimental treatments and feeding. Experimental treatments were a monensin CRC (Rumensin CRC; Provel, Division Eli Lilly Canada Inc., Guelph, $\mathrm{ON}$ ) or a placebo CRC. The monensin CRC contained $32 \mathrm{~g}$ of monensin sodium blended into a hexaglycerol distearate matrix core. According to the manufacturer, the monensin CRC delivered approximately $335 \mathrm{mg}$ of monensin on a daily basis. The placebo CRC was identical to the monensin CRC except that it did not contain monensin sodium in the core. The monensin and placebo CRC were administered via the rumen cannula at the beginning of the first experimental period and then removed at the end of the first recovery period. Treatments were switched at the beginning of the second experimental period when new monensin and placebo CRC were administered via the rumen cannula of each cow. For the initial $21 \mathrm{~d}$, experimental animals were fed a TMR ad libitum twice daily at 0700 and $1300 \mathrm{~h}$. Diet composition and chemical analysis are shown in Table 1. Individual cow feed intake was recorded daily during the experimental period. The TMR samples and orts were collected daily, stored at $-20^{\circ} \mathrm{C}$, and composited weekly. Pooled TMR and orts samples were analyzed for DM by drying in an oven at $60^{\circ} \mathrm{C}$ for $48 \mathrm{~h}$ (AOAC, 1990), and for ADF (AOAC, 1990), NDF (Goering and Van Soest, 1970), and CP using the macroKjeldahl procedure (AOAC, 1990).

Induction of SARA and continuous measurement of ruminal pH. Between d 22 and d 32 of each experimental period, SARA was induced using a nutritional model developed by Keunen et al. (2000). This experimental model consisted of restricting the intake of TMR to $85 \%$ of ad libitum intake (as determined in the preceding 7-d period) and substituting $15 \%$ grain pellets consisting of 50\% wheat and $50 \%$ barley. The feeding schedule during this period was as follows: 1) 
Table 1. Ingredient and chemical composition of the TMR fed to lactating dairy cows in Experiment 1.

\begin{tabular}{ll}
\hline Ingredient & $\%$, as fed basis \\
Corn silage & 51.7 \\
High-moisture corn & 14.9 \\
Mixed haylage & 13.1 \\
Mixed hay & 4.4 \\
Lactating cow supplement ${ }^{1}$ & 15.9 \\
Chemical composition & \\
DM, \% & 49.9 \\
& $\%$ of $\mathrm{DM}$ \\
$\mathrm{CP}(\mathrm{N} \times 6.25)$ & 17.9 \\
$\mathrm{ADF}$ & 20.3 \\
$\mathrm{NDF}$ & 38.7 \\
$\mathrm{Ca}$ & 0.79 \\
$\mathrm{P}$ & 0.44 \\
$\mathrm{~K}$ & 1.56 \\
$\mathrm{Mg}$ & 0.36 \\
$\mathrm{Na}$ & 0.16 \\
$\mathrm{NE}$ & ${ }^{2}{ }^{2 \mathrm{Mcal} / \mathrm{kg}}$ \\
\hline
\end{tabular}

${ }^{1}$ Contained (DM basis): $35.1 \% \mathrm{CP}, 85.5 \%$ RUP (\% of CP), $14.5 \%$ $\mathrm{RDP}(\%$ of $\mathrm{CP}$ ), $2.13 \% \mathrm{Ca}, 0.73 \% \mathrm{P}, 0.82 \% \mathrm{Mg}, 2.02 \% \mathrm{~K}, 0.61 \% \mathrm{~S}$, $1.09 \% \mathrm{Na}, 0.72 \% \mathrm{Cl}, 257.9 \mathrm{mg} / \mathrm{kg}$ Fe, $365.2 \mathrm{mg} / \mathrm{kg} \mathrm{Zn}, 67.6 \mathrm{mg} / \mathrm{kg}$ $\mathrm{Cu}, 177.5 \mathrm{mg} / \mathrm{kg} \mathrm{Mn}, 0.97 \mathrm{mg} / \mathrm{kg}$ Se, $0.87 \mathrm{mg} / \mathrm{kg}$ Co, $3.23 \mathrm{mg} / \mathrm{kg} \mathrm{I}$, $33,380 \mathrm{IU} / \mathrm{kg}$ of vitamin A, 13,350 IU/kg of vitamin D, $120.2 \mathrm{IU} / \mathrm{kg}$ of vitamin $\mathrm{E}$.

${ }^{2}$ Estimated using equations and values according to NRC (1989).

At $0700 \mathrm{~h}$, cows were fed $2 \mathrm{~kg}$ of the TMR; 2) At 0900 $\mathrm{h}$, cows were fed two-thirds of their daily grain pellet allowance; 3) At $1100 \mathrm{~h}$, cows were offered TMR for 30 min; 4) At $1300 \mathrm{~h}$, cows were fed the remainder (onethird) of their daily grain pellet allowance; 5) At 1500 $\mathrm{h}$, cows were offered TMR for $30 \mathrm{~min}$; and 6) At 1700 $\mathrm{h}$, cows were fed the remainder of the daily allowance of TMR. Cows were allowed 30 min for complete consumption of the grain pellets after which any grain pellets not consumed were directly introduced into the rumen via the rumen cannulae. Days 33 to 42 were considered a recovery period during which cows were maintained on treatment and had ad libitum access to the TMR. The rationale for including a recovery period was that, assuming that we observed significant effects of monensin on ruminal $\mathrm{pH}$ characteristics during SARA, we wanted to determine if monensin treatment would improve the prognosis for recovery. Ruminal $\mathrm{pH}$ was recorded on a continuous basis using indwelling $\mathrm{pH}$ probes during the SARA and recovery periods as described by Cumby et al. (2001). A pH reading was taken every second, averaged over every $60 \mathrm{~s}$, and then stored. The position of the $\mathrm{pH}$ electrode was checked daily in each cow, and the $\mathrm{pH}$ electrodes and $\mathrm{pH}$ transmitters were calibrated with $\mathrm{pH} 4$ and 7 buffer solutions (Fisher Scientific, Fairlawn, NJ) once weekly. The continuous ruminal $\mathrm{pH}$ data were summarized for each 24-h period by calculating the mean $\mathrm{pH}$, the amount of time below $\mathrm{pH} 6$ and 5.6, and the area (time $\times \mathrm{pH}$ ) below $\mathrm{pH} 6$ and 5.6.
Sample collection. Experimental cows were milked twice daily at 0500 and $1500 \mathrm{~h}$, and milk weights were recorded. During the 10-d SARA and recovery periods, milk samples were collected daily from morning and afternoon milkings, and preserved with 2-bromo-2-nitropropane-1-2-diol. Milk samples were then pooled daily based on milk yield, and pooled samples were immediately submitted to the Central Milk Testing Laboratory (Laboratory Services Division, University of Guelph, Guelph, ON) for compositional analysis. Milk samples were analyzed for $\mathrm{CP}$, fat, and lactose using a near infrared analyzer (Foss System 4000; Foss Electric, Hillerod, Denmark). Urea N was assayed colorimetrically using the diacetyl monoxime method (Sigma kit no. 535; Sigma Chemical Co., St. Louis, MO). On d 24 and 31 of the experimental period, approximately $300 \mathrm{ml}$ of ruminal fluid was collected at 0900, 1100, $1300,1500,1700$, and $1900 \mathrm{~h}$ from the ventral sac through the cannula using a probe and a vacuum pump. Ruminal fluid samples were centrifuged at $4000 \times g$, supernatants obtained, and then stored frozen at $-70^{\circ} \mathrm{C}$ until later analysis. Ruminal fluid VFA concentrations were determined following protein precipitation using the copper tungstate method on a Varian GC3400 using an 8000 autosampler and a Varian 654 data system (Varian Canada, Missisauga, ON, Canada). A fused silica capillary column was used $(15 \mathrm{~m} \times 0.53 \mathrm{~mm}$, i.d.; Nukol; Supelco Canada Ltd., Mississaugua, ON, Canada). The injection and ionization temperature was $200^{\circ} \mathrm{C}$ and was reached by gradually increasing the temperature at a rate of $5^{\circ} \mathrm{C} / \mathrm{min}$ with a holding time of $1 \mathrm{~min}$.

Statistical analysis. The ANOVA was conducted using the SAS general linear models procedure (SAS, 1990) using the following general model:

$$
\mathrm{Y}_{\mathrm{ijk}}=\mu+\alpha_{\mathrm{i}}+\beta_{\mathrm{j}}+\pi_{\mathrm{k}}+\varepsilon_{\mathrm{ijk}}
$$

where

$$
\begin{aligned}
\mathrm{Y}_{\mathrm{ijk}} & =\text { the dependent variable, } \\
\mu & =\text { overall mean } \\
\mathrm{a}_{\mathrm{i}} & =\text { effect of cow }(\mathrm{i}=1 \ldots .6), \\
\beta_{\mathrm{j}} & =\text { effect of period }(\mathrm{j}=1,2), \\
\pi_{\mathrm{k}} & =\text { effect of treatment }(\mathrm{k}=1,2), \text { and } \\
\varepsilon_{\mathrm{ijk}} & =\text { random residual error. }
\end{aligned}
$$

For dependent variables that had repeated measurements (i.e., ruminal VFA measurements), the repeated measurement option within the SAS (1990) GLM procedure was used. Effects were considered significant at a probability $P<0.05$, unless otherwise indicated. 
Table 4. Ruminal $\mathrm{pH}$ characteristics during subacute ruminal acidosis (SARA) and recovery periods in Holstein dairy cows as affected by supplementation with a monensin premix in Experiment 2 .

\begin{tabular}{lcccc}
\hline Item & Control & Monensin & SE & $P$ value \\
\hline SARA period & & & & \\
Mean pH & 6.15 & 6.12 & 0.02 & 0.45 \\
Minimum pH & 5.33 & 5.23 & 0.05 & 0.22 \\
Maximum pH & 6.81 & 6.83 & 0.02 & 0.43 \\
Minutes $\mathrm{pH}<6, \mathrm{~min} / \mathrm{d}$ & 415.0 & 461.0 & 31.1 & 0.36 \\
Area $\mathrm{pH}<6, \mathrm{~min} \mathrm{pH} / \mathrm{d}$ & 126.8 & 144.2 & 15.9 & 0.48 \\
Minutes $\mathrm{pH}<5.6, \mathrm{~min} / \mathrm{d}$ & 123.7 & 154.2 & 22.4 & 0.39 \\
Area $\mathrm{pH}<5.6, \mathrm{~min} \mathrm{pH} / \mathrm{d}$ & 25.1 & 29.1 & 4.7 & 0.58 \\
Recovery period & & & & \\
Mean $\mathrm{pH}$ & 6.24 & 6.22 & 0.07 & 0.85 \\
Minimum pH & 5.48 & 5.39 & 0.13 & 0.66 \\
Maximum $\mathrm{pH}$ & 6.91 & 6.84 & 0.07 & 0.49 \\
Minutes $\mathrm{pH}<6, \mathrm{~min} / \mathrm{d}$ & 323.4 & 329.4 & 67.4 & 0.95 \\
Area $\mathrm{pH}<6, \mathrm{~min} \mathrm{pH} / \mathrm{d}$ & 112.5 & 79.9 & 36.9 & 0.57 \\
Minutes $\mathrm{pH}<5.6, \mathrm{~min} / \mathrm{d}$ & 131.5 & 67.8 & 53.5 & 0.44 \\
Area $\mathrm{pH}<5.6, \mathrm{~min} \mathrm{pH} / \mathrm{d}$ & 33.2 & 11.9 & 12.9 & 0.31 \\
\hline
\end{tabular}

that is indicative of SARA). In the current study, ruminal $\mathrm{pH}$ was less than or equal to 5.6 for prolonged periods, and minimum ruminal $\mathrm{pH}$ attained ranged from 5.14 to 5.33 during SARA. This indicates that we achieved a simulation of SARA that is typical of dairy herds under practical conditions.

Mean $\mathrm{pH}$, amount of time per day that $\mathrm{pH}$ was below 6 and 5.6, and the area (time $\times \mathrm{pH}$ ) that $\mathrm{pH}$ was below 6 and 5.6 were not affected $(P>0.05)$ by monensin during both the grain challenge and recovery periods in the two experiments, indicating that monensin was not efficacious in increasing ruminal $\mathrm{pH}$ under the dietary conditions used in this study. Green et al. (1999) reported that monensin increased ruminal $\mathrm{pH}$ in periparturient dairy cows. Monensin inhibits lactate-producing bacteria, which proliferate in abundant starchy conditions, and a reduction in ruminal lactate concentration raises ruminal $\mathrm{pH}$ (Russell and Hino, 1985; Callaway and Martin, 1997). In feedlot experiments in which monensin was potent in preventing extreme drops in ruminal $\mathrm{pH}$ following consumption of readily fermentable carbohydrates, ruminal lactate concentrations were generally high, exceeding $5 \mathrm{mM}$ (Owens et al., 1998). However, in the nutritional model employed in this study to induce SARA, ruminal lactate concentration is less than $0.02 \mathrm{~m} M$ (see Keunen et al., manuscript accepted), and this level is much lower than the threshold of $5 \mathrm{~m} M$ above which monensin has been reported to increase ruminal pH (Owens et al., 1998; Oetzel et al., 1999). For this reason, we can surmise that SARA in our experimental cows was not lactateinduced and ruminal $\mathrm{pH}$ declined primarily as a function of VFA concentrations, and, therefore, the inhibitory effect of monensin on lactate production would have played only a minor role in the regulation of rumi-
Table 5. Ruminal $\mathrm{pH}$ and VFA characteristics during grain-induced subacute ruminal acidosis in Holstein dairy cows as affected by supplementation with a monensin controlled release capsule (CRC) or premix in Experiments 1 and 2.

\begin{tabular}{lccll}
\hline Item & Control & Monensin & SE & $P$ value \\
\hline CRC (Expt. 1) & & & & \\
VFA, m $M$ & & & \\
Acetate (A) & 105.0 & 97.2 & 2.7 & 0.10 \\
Propionate (P) & 39.1 & 41.0 & 1.7 & 0.48 \\
Butyrate & 11.7 & 10.9 & 0.3 & 0.12 \\
Isobutyrate & 0.9 & 0.8 & 0.03 & 0.10 \\
Valerate & 2.1 & 1.9 & 0.09 & 0.36 \\
Isovalerate & 1.5 & 1.4 & 0.04 & 0.10 \\
Total & 160.2 & 153.2 & 4.4 & 0.33 \\
A:P & 3.18 & 2.72 & 0.09 & 0.02 \\
Premix (Expt. 2) & & & & \\
VFA, m $M$ & & & & \\
Acetate (A) & 109.5 & 107.7 & 1.8 & 0.53 \\
Propionate (P) & 36.8 & 39.6 & 1.4 & 0.23 \\
Butyrate & 12.7 & 13.5 & 0.9 & 0.53 \\
Isobutyrate & 0.8 & 0.8 & 0.04 & 0.88 \\
Valerate & 2.1 & 1.7 & 0.1 & 0.08 \\
Isovalerate & 1.5 & 1.5 & 0.1 & 0.88 \\
Total & 163.4 & 164.8 & 1.6 & 0.56 \\
A:P & 3.29 & 2.83 & 0.11 & 0.04 \\
\hline
\end{tabular}

${ }^{1}$ Ruminal fluid spot samples were obtained at $0(0900 \mathrm{~h}$, grain pellet feeding), 2, 4, 6, 8, and $10 \mathrm{~h}$.

23-Methyl-butanoic acid.

nal $\mathrm{pH}$ in the current study. The lack of a significant effect of monensin on ruminal $\mathrm{pH}$ observed in the present study agrees with the results of Ruiz et al. (2001).

Mean ruminal VFA concentrations are shown in Table 5 for Expt. 1 and 2. In both experiments, monensin had no effect on ruminal VFA concentrations $(P>0.05)$; however, numerically, monensin decreased ruminal acetate and increased propionate concentrations. Both monensin CRC and premix reduced the acetate-to-propionate ratio, and this is in agreement with results reported by Green et al. (1999) and Ruiz et al. (2001) in dairy cows. Several studies have reported a characteristic shift in rumen fermentation, as demonstrated by changes in VFA pattern, in beef steers (Richardson et al., 1976), and dairy cows (Sauer et al., 1989). In these studies, animals treated with monensin had consistently higher ruminal concentrations of propionate, but changes in ruminal concentrations of acetate and butyrate were not consistent. These findings on ruminal VFA patterns are in agreement with the study by Green et al. (1999) with transition dairy cows fed similar diets as those fed in this study. Other studies have reported that monensin premix does not affect total VFA levels in lactating dairy cows (Haimoud et al., 1995), and in beef steers (Muntifering et al., 1980; Armentano and Young, 1983). However, a decrease in total VFA levels in vitro (Whetstone et al., 1981) and in beef steers (Lemaguer et al., 1978) has also been reported. Reasons for these discrepancies between studies may include differ- 
Table 6. DMI, milk production, and milk composition of Holstein dairy cows as affected by supplementation with monensin controlled release capsule (CRC) in Experiment 1.

\begin{tabular}{lclll}
\hline Item & Control & Monensin & SE & $P$ value \\
\hline Day 22 to 32 (SARA) & & & & \\
DMI, kg/d & 22.2 & 22.1 & 0.2 & 0.65 \\
Milk yield, kg/d & 37.0 & 35.7 & 0.6 & 0.20 \\
Fat, \% & 3.29 & 3.03 & 0.06 & 0.04 \\
Protein, \% & 3.10 & 3.13 & 0.04 & 0.64 \\
Lactose, \% & 4.85 & 4.85 & 0.02 & 0.80 \\
Fat, kg/d & 1.20 & 1.06 & 0.02 & 0.01 \\
Protein, kg/d & 1.15 & 1.12 & 0.01 & 0.06 \\
Lactose & 1.80 & 1.73 & 0.03 & 0.22 \\
MIlk urea N, mg/dL & 12.4 & 12.6 & 0.38 & 0.73 \\
Day 33 to 42 (RECOVERY) & & & & \\
DMI, kg/d & 22.6 & 23.0 & 0.2 & 0.29 \\
Milk yield, kg/d & 35.7 & 36.4 & 0.9 & 0.62 \\
Fat, \% & 3.54 & 3.22 & 0.13 & 0.20 \\
Protein, \% & 3.14 & 3.17 & 0.04 & 0.61 \\
Lactose, \% & 4.81 & 4.83 & 0.01 & 0.33 \\
Fat, kg/d & 1.23 & 1.15 & 0.04 & 0.29 \\
Protein, kg/d & 1.12 & 1.15 & 0.02 & 0.31 \\
Lactose, kg/d & 1.72 & 1.76 & 0.05 & 0.56 \\
Milk urea N, mg/dL & 12.9 & 13.2 & 0.4 & 0.55 \\
\hline
\end{tabular}

ences in dietary inclusion levels of monensin, and interactions between feed intake and composition, and monensin.

\section{Feed Intake and Milk Production}

In Expt. 1, monensin CRC did not affect $(P>0.05)$ DMI or milk yield (Table 6). In Expt 2, monensintreated cows consumed 1.5 to $2.8 \mathrm{~kg} / \mathrm{d}$ more DM compared with control cows during the SARA and recovery periods, and this difference was significant $(P<0.05$; Table 7). Concomitantly, monensin premix-treated

Table 7. DMI, milk production, and milk composition of Holstein dairy cows as affected by supplementation with a monensin premix in Experiment 2.

\begin{tabular}{lclll}
\hline Item & Control & Monensin & SE & $P$ value \\
\hline Day 22 to 32 (SARA) & & & & \\
DMI, kg/d & 19.8 & 21.3 & 0.3 & 0.03 \\
Milk yield, kg/d & 27.0 & 31.0 & 0.9 & 0.04 \\
Fat, \% & 3.38 & 3.18 & 0.04 & 0.03 \\
Protein, \% & 3.48 & 3.37 & 0.06 & 0.22 \\
Lactose, \% & 4.60 & 4.63 & 0.03 & 0.50 \\
Fat, kg/d & 0.88 & 0.98 & 0.04 & 0.12 \\
Protein, kg/d & 0.91 & 1.04 & 0.03 & 0.05 \\
Lactose, kg/d & 1.25 & 1.44 & 0.04 & 0.04 \\
Milk urea N, mg/dL & 10.2 & 10.9 & 0.56 & 0.41 \\
Day 33 to 42 (RECOVERY) & & & & \\
DMI, kg/d & 20.9 & 23.7 & 0.4 & 0.01 \\
Milk yield, kg/d & 25.9 & 29.5 & 0.5 & 0.006 \\
Fat, \% & 3.44 & 3.13 & 0.12 & 0.15 \\
Protein, \% & 3.58 & 3.44 & 0.05 & 0.14 \\
Lactose, \% & 4.62 & 4.66 & 0.03 & 0.42 \\
Fat, kg/d & 0.83 & 0.91 & 0.04 & 0.18 \\
Protein, kg/d & 0.90 & 0.99 & 0.02 & 0.02 \\
Lactose, kg/d & 1.20 & 1.37 & 0.02 & 0.01 \\
Milk urea N, mg/dL & 10.7 & 12.8 & 0.5 & 0.06 \\
\hline
\end{tabular}

cows yielded 3.6 to $4 \mathrm{~kg} / \mathrm{d}$ more milk compared to control cows, and this difference was significant $(P<0.05$; Table 7). The well-documented effects of adding monensin to dairy cow diets have been increased milk production in conjunction with no change or a decrease in DMI (Van der Werf et al., 1998; Phipps et al., 2000; Ruiz et al., 2001), thereby suggesting that monensin improved the efficiency of feed utilization. However, in the current study dairy cows were under conditions of experimentally induced SARA and direct comparisons with published studies in which monensin was supplemented under "normal" feeding conditions would be somewhat misleading. However, the lack of response in DMI and milk production in CRC-treated cows is in agreement with earlier trials (Lean et al., 1994; Hayes et al., 1996; Green et al., 1999; Vallimont et al., 2001).

In Expt. 2, the likely mechanism for the increased milk yield observed was that monensin-treated cows ate more DM. Based on dietary analysis (Table 2), we calculated that the additional 1.5 to $2.8 \mathrm{~kg}$ of DMI would correspond with 2.3 to $4.2 \mathrm{Mcal}$ of additional $\mathrm{NE}_{\mathrm{L}}$ intake. In the present study, mean milk fat, protein, and lactose contents were $32.6,33.8$ and $46.1 \mathrm{~g} / \mathrm{kg}$ milk for monensin-treated cows (Table 7), and if we assume caloric values of $9.3,5.9$, and $4.0 \mathrm{kcal} / \mathrm{g}$ of fat, protein, and lactose, respectively (Arieli et al., 2001), then the extra $\mathrm{NE}_{\mathrm{L}}$ intake could correspond to an additional 1.5 to $2.9 \mathrm{~kg} / \mathrm{d}$ of milk in monensin-treated cows. Monensintreated cows did produce 2 to $4 \mathrm{~kg} / \mathrm{d}$ more milk compared to placebo cows. The magnitude of this increase (7 to $14 \%$ ) in milk production is similar to that recorded in previous studies using similar dose rates of monensin (Wade et al., 1996; Phipps et al., 2000). However, the milk yield response is higher compared with that of 4 to $6.5 \%$ generally reported in the literature (Van der Werf et al., 1998; Duffield et al., 1999; Ruiz et al., 2001). In Expt. 2, an interesting observation is that both DMI and milk yield were not affected by monensin during the initial 3-wk adaptation period (data not shown), and significant responses were only detected when SARA was imposed. We speculate that there was some unknown interaction between monensin and SARA. It is plausible that during SARA, monensin provided a prophylactic effect that allowed a more rapid adaptation to grain feeding, thereby minimizing or avoiding ruminal digestive disturbances. Additional research is needed to elucidate the effects of monensin on digestive function, specifically ruminal fiber degradation and total tract diet digestibility during SARA.

In Expt. 1, treatment with monensin consistently reduced milk fat content by 0.26 to 0.32 percentage units, and these effects were significant $(P=0.04)$ during SARA (Table 6). In Expt. 2, treatment with monensin reduced milk fat content by 0.20 to 0.31 percentage 
units, and these differences were significant $(P=0.03)$ during SARA. The observed decrease in milk fat content due to the administration of monensin has been reported in other studies (Van der Werf et al., 1998; Phipps et al., 2000; Vallimont et al., 2001), but not others (Duffield et al., 1999; Green et al., 1999). In Expt. 1 , treatment with monensin CRC reduced $(P=0.01)$ milk fat yield during SARA (Table 6). Even though monensin treatment reduced milk fat content in Expt. 2 , milk fat yield was unaffected $(P>0.05$; Table 7$)$, primarily because monensin elevated milk yield. During the recovery period, milk fat content in control cows returned to pre-SARA levels (data not shown), whereas milk fat content remained depressed in monensintreated cows, perhaps indicating that there is an additive effect of monensin and grain feeding on milk fat content. Further studies are needed to compare the effects of monensin and different forage-to-concentrate ratios on milk fat production.

In Expt. 1, milk contents and yields of protein were unaffected $(P>0.05)$ by monensin (Table 6$)$. In Expt 2 , monensin treatment had no effect $(P>0.05)$ on milk protein content (Table 7); however, primarily because of higher milk yield in monensin-treated cows, milk protein yield was higher due to monensin treatment during SARA $(P=0.05)$ and recovery $(P=0.02)$ periods (Table 7). Phipps et al. (2000) reported that monensin treatment significantly reduced milk protein content in a study with a much larger sample size than the current study. However, in other studies (Van der Werf et al., 1998; Duffield et al., 1999; Green et al., 1999; Ruiz et al., 2001), monensin had no effect on milk protein content.

In Expt. 1, milk lactose content was unaffected $(P>$ 0.05 ) by addition of monensin (Table 6). In Expt. 2, milk lactose content was unaffected $(P>0.05)$ by monensin treatment; however, milk lactose yield was higher in monensin-treated compared with control cows during the SARA $(P=0.04)$ and recovery $(P=0.01)$ periods (Table 7). This response was primarily due to higher milk production as a result of monensin treatment in Expt. 2. Other studies did not detect any effects of monensin on milk lactose content or yield (Green et al., 1999; Phipps et al., 2000; Vallimont et al., 2001). In both experiments, milk urea $\mathrm{N}$ was unaffected by treatment with monensin and this agrees with earlier studies (Vallimont et al., 2001).

\section{CONCLUSIONS}

In summary, the administration of monensin either as CRC or premix had no effect on ruminal $\mathrm{pH}$ characteristics under conditions of SARA. In addition, monensin CRC had no effect on milk production, but monensin premix was observed to increase DMI and milk yield. Even though monensin did not increase ruminal $\mathrm{pH}$ during SARA, it is conceivable that there is an interaction between monensin and SARA that allowed monensin-treated cows to adapt faster to additional grain feeding, thereby maintaining DMI and milk yield. Additional research characterizing the effects of monensin on ruminal function, specifically fiber degradation, is needed to aid us in further understanding this interaction.

\section{ACKNOWLEDGMENTS}

The authors would like to thank the staff of the Elora Dairy Research Centre (University of Guelph) for their technical assistance and Provel, Division Eli Lilly Canada Inc. (Guelph, ON, Canada) for financial support. We also would like to acknowledge the continued support received from the Ontario Ministry of Agriculture, Food and Rural Affairs (OMAFRA), and the Natural Sciences and Engineering Research Council of Canada (BWM).

\section{REFERENCES}

Association of Official Analytical Chemists. 1990. Official Methods of Analysis. 15th Ed. AOAC, Arlington, VA.

Arieli, A., S. Abramson, S. J. Mabjeesh, S. Zamwel, and I. Bruckental 2001. Effect of site and source of energy supplementation on milk yield in dairy cows. J. Dairy Sci. 84:462-470.

Armentano, L. E., and J. W. Young. 1983. Production and metabolism of volatile fatty acids, glucose and $\mathrm{CO}_{2}$ in steers and the effects of monensin on volatile fatty acids kinetics. J. Nutr. 113:1265-1277.

Bergen, W. G., and D. B. Bates. 1984. Ionophores: Their effect on production efficiency and mode of action. J. Anim. Sci. 58:1465-1483.

Burrin, D. G., and R. A. Britton. 1986. Response to monensin in cattle during subacute acidosis. J. Anim. Sci. 63:888-893.

Callaway, T. R., and S. A. Martin. 1997. Effects of cellobiose and monensin on in vitro fermentation of organic acids by mixed ruminal bacteria. J. Dairy Sci. 80:1126-1135.

Cooper, R., and T. J. Klopfenstein. 1996. Effect of Rumensin and feed intake variation on ruminal $\mathrm{pH}$. Pages A1-A14 In Scientific Update on Rumensin/Tylan/Micotil for the Professional Feedlot Consultant. Elanco Animal Health, Indianapolis, IN.

Cumby, J. L., J. C. Plaizier, I. Kyriazakis, and B. W. McBride. 2001. Effect of subacute ruminal acidosis on the preference of cows for pellets containing sodium bicarbonate. Can. J. Anim. Sci. 81:149-152.

Duffield, T. F., D. Sandals, K. E. Leslie, K. Lissemore, B. W. McBride, J. H. Lumsden, P. Dick, and R. Bagg. 1998a. Effect of prepartum administration of monensin in a controlled-release capsule on postpartum energy indicators in lactating dairy cows. J. Dairy Sci. 81:2354-2361.

Duffield, T. F., K. E. Leslie, D. Sandals, K. Lissemore, B. W. McBride, J. H. Lumsden, P. Dick, and R. Bagg. 1998b. Efficacy of monensin for the prevention of subclinical ketosis in lactating dairy cows. J. Dairy Sci. 82:2866-2873.

Duffield, T. F., K. E. Leslie, D. Sandals, K. Lissemore, B. W. McBride, J. H. Lumsden, P. Dick, and R. Bagg. 1999. Effect of prepartum administration of monensin in a controlled-release capsule on milk production and milk components in early lactation. J. Dairy Sci. 82:272-279.

Garrett, E. F., M. N. Pereira, K. V. Nordlund, L. E. Armentano, W. J. Goodger, and G. R. Oetzel. 1999. Diagnostic methods for the 
detection of subacute ruminal acidosis in dairy cows. J. Dairy Sci. 82:1170-1178.

Goering, H. K., and P. J. Van Soest. 1970. Forage fibre analyses (apparatus, reagents, procedures, and some applications). Agric. Handbook No. 379. ARS-USDA, Washington, DC.

Green, B. L., B. W. McBride, W. D. Sandals, K. E. Leslie, R. Bagg, and P. Dick. 1999. The impact of the monensin controlled release capsule upon subclinical acidosis in the transition dairy cow. J. Dairy Sci. 82:333-342.

Haimoud, D. A., M. Vernay, C. Bayourthe, C., and R. Moncoulon. 1995. Avoparcin and monensin effects on the digestion of nutrients in dairy cows fed a mixed diet. Can. J. Anim. Sci. 75:379-385.

Hayes, D. P., D. U. Pfeiffer, and N. B. Williamson. 1996. Effect of intraruminal capsules on reproductive performance and milk production of dairy cows fed pasture. J. Dairy Sci. 79:1000-1008.

Keunen, J. E., J. C. Plaizier, I. Kyriazakis, T. F. Duffield, and B. W. McBride. 2000. Creating a nutritional model to induce subacute ruminal acidosis in the dairy cow. J. Dairy Sci. 78 (Suppl. 1):263 (Abstr.).

Keunen, J. E., J. C. Plaizier, I. Kyriazakis, T. F. Duffield, T. M. Widowski, M. I. Lindinder, and B. W. McBride. 2002. Effects of a subacute ruminal acidosis model on the diet selection of dairy cows. J. Dairy Sci. (accepted).

Lean, I. J., M. Curtis, R. Dyson, and B. Lowe. 1994. Effects of sodium monensin on reproductive performance of dairy cattle. Effects on conception rates, calving to conception intervals, calving to heat and milk production in dairy cows. Aust. Vet. J. 71:273-277.

Lemaguer, R. P., F. N. Owens, B. J. Shockey, K. S. Lusby and R. Totusek. 1978. Monensin effect on rumen turnover rate, twenty four-hour VFA patters, nitrogen components and cellulose disappearance. J. Anim. Sci. 47:255-261.

Muntifering, R. B., B. Theurer, R. S. Swingle, and H. W. Hale. 1980. Effect of monensin on nitrogen utilization and digestibility of concentrate diets by steers. J. Anim. Sci. 50:930-936.

Nagaraja, T. G., T. B. Avery, S. J. Galitzert, and D. L. Holman. 1985. Effect of ionophore antibiotics on experimentally induced lactic acidosis in cattle. Am. J. Vet. Res. 46:2444-2452.

Nocek, J. E. 1997. Bovine acidosis: Implications on laminitis. J. Dairy Sci. 80:1005-1028.

NRC. 1989. National Research Council. Nutrient requirements of dairy cattle. 6th Revised Ed. National Academy Press. Washington, DC.

Oetzel, R. R., K. V. Nordlund, and E. F. Garret. 1999. Effect of ruminal $\mathrm{pH}$ and stage of lactation on ruminal lactate concentration in dairy cows. J. Dairy Sci. 82 (Supp.1):38.

Owens, F. N., D. S. Secrist, W. J. Hill, and D. R. Gill. 1998. Acidosis in cattle: A review. J. Anim. Sci. 76:275-286.

Phipps, R. H., J. I. D. Wilkinson, L. J. Jonker, M. Tarrant, A. K. Jones, and A. Hodge. 2000. Effect of monensin on milk production of Holstein-Friesian dairy cows. J. Dairy Sci. 83:2789-2794.
Plaizier, J. C., A. Martin, T. F. Duffield, R. Bagg, P. Dick, and B. W. McBride. 2000. Effect of a prepartum administration of monensin in a controlled-release capsule on apparent digestibilities and nitrogen utilization in transition dairy cows. J. Dairy Sci. 83:2918-2925.

Ramanzin, M., L. Bailoni, S. Schiavon, and G. Bittante. 1997. Effect of monensin on milk production and efficiency of dairy cows fed two diets differing in forage to concentrate ratios. J. Dairy Sci. 80:1136-1142.

Richardson, L. F., A. P. Raun, E. L. Potter, C. O. Cooley, and R. P. Rathmacher. 1976. Effect of monensin on rumen fermentation in vitro and in vivo. J. Anim. Sci. 43:657-664.

Ruiz, R., G. L. Albrecht, L. O. Tedeschi, G. Jarvis, J. B. Russell, and D. G. Fox. 2001. Effect of monensin on the performance and nitrogen utilization of lactating dairy cows consuming fresh forage. J. Dairy Sci. 84:1717-1727.

Russell, J. B., and T. Hino. 1985. Regulation of lactate production in Streptococcus bovis: A spiraling effect that contributes to rumen acidosis. J. Dairy Sci. 68:1712-1721.

Russell, J. B., and H. J. Strobel 1989. Effect of ionophores on ruminal fermentation. Appl. Environ. Microbiol. 55:1-6.

SAS User's Guide. Statistics. Version 6 Edition. 1990. SAS Inst., Inc., Cary, NC

Sauer F. D., V. Fellner, R. Kinsman, J. K. Kramer, H. A. Jackson, A. J. Lee, and S. Chen. 1998. Methane output and lactation response in Holstein cattle with monensin or unsaturated fat added to the diet. J. Anim. Sci. 76:906-914.

Sauer, F. D., J. K. G. Kramer, and W. J. Cantwell. 1989. Antiketogenic effects of monensin in early lactation. J. Dairy Sci. 72:436-442.

Schelling, G. T. 1984. Monensin mode of action in the rumen. J. Anim. Sci. 58:1518-1527.

Vallimont, J. E., G. A. Varga, A. Arieli, T. W. Cassidy, and K. A. Cummins. 2001. Effects of prepartum somatotropin and monensin on metabolism and production of periparturient Holstein dairy cows. J. Dairy Sci. 84:2607-2621.

Van der Werf, J. H. J., L. J. Jonker, and J. K. Oldenbroek. 1998. Effect of monensin on milk production by Holstein and Jersey cows. J. Dairy Sci. 81:427-433.

Wade, L., B. Granzin, and B. Lowe. 1996. The effect of monensin in dairy rations on milk production and in reducing the severity of ketosis. Pages 289-290 in Proc. 19th World Buiatrics Conference, Edinburgh, Scotland.

Weiss, W. P., and B. A. Amiet. 1990. Effect of lasalocid on performance of lactating dairy cows. J. Dairy Sci. 73:153-162.

Whetstone, H. D., C. L. Davis, and M. P. Bryant. 1981. Effect of monensin on breakdown of protein by ruminal micro-organisms in vitro. J. Anim. Sci. 53:803-809.

Yang, C.-M.J., and J. B. Russell. 1993. The effect of monensin supplementation on ruminal ammonia accumulation in vivo and the numbers of amino acid-fermenting bacteria. J. Anim. Sci. $71: 3470-3476$. 